\title{
Antibacterial Activities of different Fractions obtained from Methanolic Extracts of Allium sativum bulbs and Gacinia kola Seeds
}

\section{Agboola Temitope Deborah ${ }^{1 *}$, Feruke-Bello Yetunde $^{2}$, Ikuesan Felix Adeleke ${ }^{1}$}

Department of Biological Sciences, Olusegun Agagu University of Science and Technology Okitipupa, Nigeria.

Department of Microbiology, Hallmark University Ijebu-Itele, Nigeria

*Corresponding author

\begin{abstract}
Antibacterial activities of different fractions obtained from crude methanolic extracts of Allium sativum and Garcinia kola and their time kill assay were investigated individually and in combined form. Standard methods were used and test organisms include: Bacillus cereus, B. subtilis, B. anthracis, B. stearothermophilus, Clostridium sporogenes, Corynebacterium pyogens, Staphylococcus aureus, Enterococcus faecalis, Micrococcus luteus, Escherichia coli, Klebsiella pneumoniae, Psedomonas aeruginosa, Salmonella sp., Shigella sp., and Proteus vulgaris. Chloroform fraction of G. kola exhibited broad spectrum effect on the test isolates while butanol fraction of A. sativum exhibited narrow spectrum effect on three Gram negative isolates. When the same fractions from each plant's extract were combined at equal concentration and subjected to time kill assay, combined butanol fraction showed an excellent result with the ability of killing 100\% of Staphilococcus aureus within 90 min at $0.66 \mathrm{mg} / \mathrm{ml}$ and $100 \%$ of Klebsiella pneumonia cells within 60 min at $1.32 \mathrm{mg} / \mathrm{ml}$.Garcinia kola seeds and Allium sativum bulb extracts when combined had a broad spectrum antibacterial activity, with the combined butanol fractions being bactericidal as seen in the killing rate within short period and at a low concentration and this could be an important way of overcoming issues of antibiotic resistance.
\end{abstract}

Keywords-Antibacterial, Garcinia kola, Allium sativum, Methanolic extract, Time kill assay.

\section{INTRODUCTION}

Plant materials had been the oldest method of combating infections and diseases with different types of plant and various parts been used in numerous parts of the world to treat human ailments (1). This is because plants contain diverse chemical substances like phenols, quinones, flavonoids, tannins and coumarins (2) which show antibacterial and antifungal effect and act as means by which plant defend themselves against pathogens (3). Continuous use of antibiotics for treating ailment in human had led to the development of resistant in bacteria and mechanism adopted include; alteration of target site, enzyme inactivation and efflux pump (4). Assessment of compounds that were biologically active from plants and antibacterial activities depend greatly on the solvent utilized during the process of extraction. Although, water is universally used as solvent to extract plants products with antimicrobial activity whereas plant extracts extracted with organic solvents had been said to have greater antimicrobial effect in comparison to water extracts (5).

A study reported chloroform (out of about twenty different solvent used) as the best solvent in extracting non-polar compounds which are biologically active (6). Another study reported chloroform extracted material to possess the highest zone of inhibition against Candida (7). Due to the aromatic nature of most organic compound found to possess antimicrobial activities, they are often extracted using methanol and ethanol while other solvent include dichloromethane, acetone, and hexane. Researchers also combine solvents in order to get the best extraction of compounds. A study was conducted on different solvent to assess their ability to dissolve antimicrobials from plants, extraction rate, 
ease of its removal from the extract, toxicity and acetone have highest rating in the overall tests(8).

Garcinia kola is a member of the Guittiferae's family and often called bitter kola while Allium sativumbelong to the Family Liliaceae. G. kola had been reported to be useful in treating bronchitis, liver disorders, hepatitis, diarrhoea, laryngitis, and gonorrhoea (9). A. sativum are been used in some parts of Africa due to their important ability in preventing heart, cardiovascular disease (10) and it has been said that use of garlic regularly may help in preventing cancer, to treat malaria, and to boost immunity.

Assessment of antibacterial activities of G. kola seeds showed that activity has been demonstrated for the aqueous, ethanolic, acetone and petroleum ether extracts (11) (12). Another study also reported the antimicrobial potential of the methanol extract of G. kola seeds and fractions obtained from the extract (9).

A scientist (13) reported the antibacterial effect of various extracts of garlic and evaluated the effects of crude extracts on glycogen glucoamylase, in vitro. Another study reported the ability of garlic extract and its fractions to inhibit the growth of Enterobacteriaceae sp obtained from sprouted Mung bean (14). Therefore, this study assessed the antibacterial effect of various fractions obtained from methanolic seeds extract of Garcinia kola and Allium sativum bulb individually and in combined form on some selected bacterial isolates and also examined the rate at which these fractions killed bacterial isolates.

\section{MATERIALS AND METHODS}

\section{Collection of plant materials, preparation and process of extraction}

Seeds of G. kola and bulbs of A. sativum were purchased from Central Market Ile - Ife in the year 2013 and identified at the department of Botany Obafemi Awolowo University Ile - Ife. The methanolic extraction was done by weighing $550 \mathrm{~g}$ of each of the powdered plant materials into flat bottom flask separately containing 60\% methanol. These flasks was swirled to mix and left for four days and regularly agitated after which the mixture were filtered with Whatman filter paper No 1 to obtain clear solution of the extract. The methanolic filtrates of $G$. kola seeds and A. sativum bulbs were then evaporated using a rotary evaporator and lyophilized. The yield obtained from Garcinia kola seeds was $115 \mathrm{~g}$ and that of Allium sativum bulbs was $125 \mathrm{~g}$.

\section{Separation of the crude extract into different fractions}

About $50 \mathrm{~g}$ each of the crude extracts were dissolved in 300 $\mathrm{ml}$ of pre-sterilized deionized water and poured into a separating funnel and extracted with $n$-hexane $(5 \times 200)$. The n-hexane fractions were concentrated using rotary evaporatorand these did not yield anything. The resulting aqueous solution was re-concentrated in vacuo to remove traces of $n$-hexane. The residues were further extracted with chloroform $(5 \times 200 \mathrm{ml})$. The chloroform fractions obtained were also concentrated and lyophilized and $8.32 \mathrm{~g}$ powder was obtained from Garcinia kola extract while $6.45 \mathrm{~g}$ was obtained from Allium sativum extract which were stored and maintained at $-20^{\circ} \mathrm{C}$ for further use. The ethylacetate fraction (5.14 g for G. kola and $5.5 \mathrm{~g}$ for A. sativum) and butanol (7.5 g for G. kola and $8.75 \mathrm{~g}$ for A. sativum) fractions were also obtained by similar process. The aqueous phase remaining were freeze-dried and yielded $25.23 \mathrm{~g}$ for $\mathrm{G}$. kola and $27.15 \mathrm{~g}$ for A. sativum which were stored as stated earlier (9).

\section{Assessment of antimicrobial activity of plant's material}

The agar-wells diffusion assay as described previously (9) was used to confirm the antibacterial effects of different fractions of the plant extracts on the test isolates. Eighteen hours old broth culture of the test isolates were standardized (0.5 McFarland) before use and sub-cultured on MuellerHinton agar by uniformly seeding the agar plates with the inoculums suspension. Plant extract solutions $(35 \mathrm{mg} / \mathrm{ml})$ were dispensed into wells bored with the use of sterilized cork borer (6 $\mathrm{mm}$ diameter) in the agar medium separately and in-combination $(35 \mathrm{mg} / \mathrm{ml})$ and streptomycin $(1 \mathrm{mg} / \mathrm{ml})$ as positive control.

The plates were left on the bench for $1 \mathrm{~h}$ to allow solution diffuse properly into the medium before incubating the plates for $24 \mathrm{~h}$ at $37^{\circ} \mathrm{C}$. Zones of inhibition were examined on the plates and measured in millimeter (using ruler). The experiments were performed in duplicates.

\section{Dermination of minimum inhibitory concentrations (MICs) exhibited by the extract on test bacteria}

The MICs of the extracts were assessed as previously described (15). Plant extracts were diluted in two-folds to vary the concentration of the plant extracts solution. An aliquot of plant extracts solutions $(2 \mathrm{ml})$ were dispensed into $18 \mathrm{ml}$ of sterile mueller Hinton agar at $40^{\circ} \mathrm{C}$ transferred into petri plates and left to solidified. The procedure was repeated with various concentrations of the plant solution. The final 
concentrations used ranges from $0.078 \mathrm{mg} / \mathrm{ml}$ and $10 \mathrm{mg} / \mathrm{ml}$. Agar plates without the plant extract were used as controls. All plates were incubated for up to $48 \mathrm{~h}$ at $37^{\circ} \mathrm{C}$ and examined for presence of growth or otherwise. Lowest concentration that inhibited visible bacterial growth was taking as MIC.

\section{Determination of the rate at which the active fractions killed the test bacteria}

The rate and extent to which the active fractions of the plant extract killed the test bacteria were determined using the method described earlier by (16). Experiments were carried out by using each of the active fractions on $S$. aureus and $K$. pneumoniae as representative of each of the groups of organisms in relation to Gram reaction. Viable counts on the test organisms were pre-determined. About $0.5 \mathrm{ml}$ of a known cell density (by viable counts $10^{6} \mathrm{cFu} / \mathrm{ml}$ ) from each test bacteria suspensions were dispensed into $4.5 \mathrm{ml}$ of the active fractions at various concentrations. The solutions were mixed very well and held at $28-30^{\circ} \mathrm{C}$ and the rate of killing were determined within $2 \mathrm{~h}$ of exposure. An aliquot of $0.5 \mathrm{ml}$ of the solution were withdrawn at set time interval and dispensed into $4.5 \mathrm{ml}$ nutrient broth that contain 3\% "Tween 80 " as recovery media so as to neutralize the antimicrobial effect from the test solutions. The suspensions were mixed very well and then diluted up to $10^{-5}$ in sterilized normal saline with $0.5 \mathrm{ml}$ of the final dilution of the test organisms transferred into sterile nutrient agar at $45^{\circ} \mathrm{C}$ and plated out. The plates were left to solidified and incubated for $48 \mathrm{~h}$ at $37^{\circ} \mathrm{C}$. Control experiment without the addition of extracts was set up. Viable counts were carried out in replicates for the sample. Reduction in the cell counts means killing of the cells by the antibacterial compounds.

\section{RESULTS AND DISCUSSION}

The chloroform fraction of G. kola exhibited antibacterial effect on all the used bacteria with the exception of $C$. pyogenes. The zones of inhibition obtained with the chloroform fraction ranges from $10 \pm 1.41 \mathrm{~mm}$ and $27 \pm 1.41$ $\mathrm{mm}$. Butanol and Ethylacetate fractions were active against seven bacterial isolates used and with inhibitory zones that ranges from $12 \pm 0.00 \mathrm{~mm}$ to $21 \pm 0.71 \mathrm{~mm}$ and $15 \pm 1.41$ $\mathrm{mm}$ to $18 \pm 0.00 \mathrm{~mm}$ respectively (Table 1 ).

The highest inhibitory zone obtained by chloroform fraction was against Staphilococcus aureus $(27 \pm 1.00 \mathrm{~mm})$ while the lowest zone of inhibition $(10 \pm 1.41 \mathrm{~mm})$ was against Salmonella as in table 1. Broad spectrum antibacterial effect observed in this research agrees with the findings (17) who observed antimicrobial potential against $S$. aureus and $K$. pneumonia. Inhibitory effect of chloroform fraction of $G$. kola seeds obtained from this study fall within the same range with the result of (18) who examined the antimicrobial activities of chloroform extract of $G$. kola root with zones of inhibition ranging between $2.7 \mathrm{~mm}$ and $30.7 \mathrm{~mm}$. The result obtained from this fraction implies that chloroform is an important solvent for the extracting of biologically active components.

Butanol fraction of A. sativum show antibacterial activity against only $K$. pneumoniae, $M$. luteus and $P$. vulgaris at 35 $\mathrm{mg} / \mathrm{ml}$ and the zones of inhibition ranges from $12 \pm 0.00 \mathrm{~mm}$ to $18 \pm 1.41 \mathrm{~mm}$. All bacterial isolate tested were resistant to ethylacetate fraction except $P$. vulgaris having $14 \pm 1.00 \mathrm{~mm}$ zone of inhibition. The chloroform fraction showed antimicrobial activity against $M$. luteus and $P$. vulgaris out of all the tested organisms with zones of $15 \pm 0.71$ and $12 \pm 0.00$ respectively. The highest zone of inhibition obtained by butanol fraction on P. vulgaris was $18 \pm 1.41 \mathrm{~mm}$ while the lowest zone was on $K$. pneumoniae $(12 \pm 0.00 \mathrm{~mm})$.

Meanwhile, K. pneumonia and $P$. vulgaris were resistant to the crude methanolic extract of $A$. sativum in the previous research before separating it into different fractions and this signify the fact that different solvent extract different bioactive compound which could be active against different microorganisms.

Since chloroform fraction of the methanolic G. kola extract and butanol fraction of the crude extract of the A. sativum bulbs were the most active fractions against the used isolates, antibacterial potential of the combined chloroform fraction and combined butanol fraction of the two extracts were determined. Combined butanol fractions of G. kola and A. sativum have antibacterial effect on all the tested bacteria with the exception of $C$. sporogenes. Zones of inhibition ranged between $12 \pm 0.00 \mathrm{~mm}$ and $21 \pm 1.06 \mathrm{~mm}$. All the tested bacterial isolates were sensitive to the antimicrobial activity of the combined chloroform fraction of G. kola and A. sativum except $C$. pyogenes with zones of inhibition ranging between $12 \pm 0.00 \mathrm{~mm}$ and $21 \pm 1.41 \mathrm{~mm}$. These implied broad spectrum activities by the combined fractions. 
International Journal of Environment, Agriculture and Biotechnology, 5(3)

May-Jun, 2020 / Available: https://ijeab.com/

Table 1: The sensitivity pattern exhibited by fractions obtained from methanolic extract of Garcinia kola against bacterial isolates.

\begin{tabular}{llll}
\hline Zones of Inhibition $\left(\mathbf{m m}^{* *}\right)$ & & & \\
Bacterial isolates & $\begin{array}{c}\mathrm{GC} \\
\mathrm{mg} / \mathrm{ml})\end{array}$ & $(35 \mathrm{mg} / \mathrm{ml})$ & $\begin{array}{l}\mathrm{GB} \\
(35 \mathrm{mg} / \mathrm{ml})\end{array}$ \\
\hline B. anthracis (LIO) & $17 \pm 1.00$ & 0 & 0 \\
\hline B. cereus (NCIB 6349) & $19 \pm 1.41$ & & 0 \\
\hline B. stearothermophilus & $20 \pm 0.00$ & $16 \pm 0.00$ & $12 \pm 0.00$ \\
\hline B. subtilis (NCIB 3610) & $12 \pm 0.00$ & 0 & 0 \\
\hline C. sporogenes (NCIB 532) & $23 \pm 1.30$ & $17 \pm 1.41$ & $17 \pm 1.41$ \\
\hline C. pyogenes (LIO) & 0 & 0 & 0 \\
\hline E. coli (NCIB 86) & $23 \pm 1.41$ & $16 \pm 0.00$ & 0 \\
\hline K. pneumonia (NCIB 418) & $19 \pm 1.00$ & $17 \pm 0.71$ & $17 \pm 0.00$ \\
\hline M. luteus (NCIB 196) & $14 \pm 1.21$ & 0 & 0 \\
\hline P. vulgaris (LIO) & $25 \pm 1.21$ & $15 \pm 1.41$ & $20 \pm 0.00$ \\
\hline Ps. Aeruginosa & $17 \pm 1.28$ & $18 \pm 0.00$ & $21 \pm 0.71$ \\
\hline Salmonella (LIO) & $10 \pm 1.41$ & 0 & 0 \\
\hline Shigella (LIO) & & & $20 \pm 0.00$ \\
\hline S.aureus (NCIB 8588) & $27 \pm 1.41$ & $17 \pm 1.41$ & $13 \pm 1.41$ \\
\hline E. faecalis (LIO) & $19 \pm 1.21$ & 0 & $14 \pm 0.00$ \\
\hline
\end{tabular}

Key: $\mathrm{LIO}=$ Locally Isolated Organisms, $\mathrm{NCIB}=$ National Collection of Industrial Bacteria, $\mathrm{mm}^{* *}=$ mean of two replicates, $0=\mathrm{Not}$ sensitive, $\mathrm{GC}=$ Chloroform fraction, $\mathrm{GE}=$ Ethylacetate fraction, $\mathrm{GB}=$ Buthanol fraction.

Table 2: The sensitivity pattern exhibited by active fractions obtained from crude extract of Allium sativum, combined chloroform, combined butanol and streptomycin

\begin{tabular}{|c|c|c|c|c|c|c|}
\hline \multicolumn{7}{|c|}{ Zones of Inhibition $\left(\mathrm{mm}^{* *}\right)$} \\
\hline Bacterial isolates & $\begin{array}{c}\mathrm{AC} \\
(35 \mathrm{mg} / \mathrm{ml})\end{array}$ & $\begin{array}{c}\mathrm{AE} \\
(35 \mathrm{mg} / \mathrm{ml})\end{array}$ & $\begin{array}{c}\mathrm{AB} \\
(35 \mathrm{mg} / \mathrm{ml})\end{array}$ & $\begin{array}{l}\text { C-CHLORO } \\
(35 \mathrm{mg} / \mathrm{ml})\end{array}$ & $\begin{array}{l}\text { C-BUT } \\
(35 \mathrm{mg} / \mathrm{ml})\end{array}$ & $\begin{array}{l}\text { Streptomycin } \\
(1 \mathrm{mg} / \mathrm{ml})\end{array}$ \\
\hline B. anthracis (LIO) & 0 & 0 & 0 & $14 \pm 0.00$ & $12 \pm 0.00$ & $28 \pm 0.76$ \\
\hline B. cereus (NCIB 6349) & 0 & 0 & 0 & $16 \pm 0.71$ & $15 \pm 0.00$ & $26 \pm 0.50$ \\
\hline B. stearothermophilus & 0 & 0 & 0 & $19 \pm 0.71$ & $14 \pm 1.00$ & $30 \pm 0.58$ \\
\hline B. subtilis (NCIB 3610) & 0 & 0 & 0 & $16 \pm 0.00$ & $16 \pm 0.60$ & $27 \pm 1.00$ \\
\hline C.sporogenes (NCIB 532) & 0 & 0 & 0 & $18 \pm 0.00$ & 0 & $30 \pm 0.50$ \\
\hline C. pyogenes (LIO) & 0 & 0 & 0 & 0 & $16 \pm 0.71$ & $24 \pm 0.00$ \\
\hline E. $\operatorname{coli}(\mathrm{NCIB} 86)$ & 0 & 0 & 0 & $21 \pm 1.41$ & $17 \pm 0.00$ & $26 \pm 0.00$ \\
\hline K. pneumonia (NCIB 418) & 0 & 0 & $12 \pm 1.06$ & $16 \pm 0.00$ & $13 \pm 1.41$ & $24 \pm 1.00$ \\
\hline M. luteus (NCIB 196) & $12 \pm 0.00$ & 0 & $12 \pm 1.06$ & $13 \pm 0.60$ & $14 \pm 0.35$ & $25 \pm 0.50$ \\
\hline
\end{tabular}




$\begin{array}{llllllc}\text { P. vulgaris (LIO) } & 15 \pm 0.71 & 14 \pm 0.00 & 18 \pm 1.41 & 18 \pm 0.00 & 17 \pm 0.71 & 26 \pm 1.00 \\ \text { Ps. Aeruginosa } & 0 & 0 & 0 & 17 \pm 1.41 & 21 \pm 1.06 & 20 \pm 0.00 \\ \text { Salmonella } \text { (LIO) } & 0 & 0 & 0 & 12 \pm 0.00 & 18 \pm 0.00 & 0 \pm 0.00 \\ \text { Shigella } \text { (LIO) } & 0 & 0 & 0 & 14 \pm 0.00 & 13 \pm 1.41 & 20 \pm 1.00 \\ \text { S. aureus (NCIB 8588) } & 0 & 0 & 0 & 13 \pm 0.71 & 20 \pm 0.71 & 29 \pm 1.50 \\ \text { E. faecalis (LIO) } & 0 & 0 & 0 & 13 \pm 1.41 & 13 \pm 0.71 & 20 \pm 2.00\end{array}$

Key: $\overline{L I O}=$ Locally Isolated Organisms, $\mathrm{NCIB}=$ National Collection of Industrial Bacteria, $\mathrm{mm}^{* *}=$ mean of two replicates, $0=$ Not sensitive, $\mathrm{AC}=$ Chloroform fraction, $\mathrm{AE}=$ Ethylacetate fraction, $\mathrm{AB}=$ Buthanol fraction, $\mathrm{C}-\mathrm{CHLORO}=\mathrm{Combined}$ Chloroform and $\mathrm{C}-\mathrm{BUT}=$ Combined Buthanol fraction.

Minimum inhibitory concentrations shown by combination of chloroform and butanol fractions of the crude extracts against the isolates were as in Table 3. The MIC exhibited by combining both the butanol fractions (C-but) of the two plants extracts ranged between $0.22 \mathrm{mg} / \mathrm{ml}$ and $3.5 \mathrm{mg} / \mathrm{ml}$ while MIC exhibited by combination of chloroform fractions (C-chloro) of the two plant extracts ranged between 0.11 $\mathrm{mg} / \mathrm{ml}$ and $3.5 \mathrm{mg} / \mathrm{ml}$. Combined chloroform fractions obtained from methanolic extracts of $G$. kola and A. sativum showed MIC of $0.11 \mathrm{mg} / \mathrm{ml}$ for $E$. coli and $0.88 \mathrm{mg} / \mathrm{ml}$ for $B$. anthracis, B. cereus and M. luteus. Combined butanol fractions showed MIC of $0.22 \mathrm{mg} / \mathrm{ml}$ and $1.75 \mathrm{mg} / \mathrm{ml}$ respectively for these organisms (Table 4). Considering the MICs stated above, the result of this study is still in agreement with the result of (19) who stated that, extract showing MIC below $100 \mathrm{mg} / \mathrm{ml}$ has a good activity.

Table 3: The minimum inhibitory concentrations exhibited by combined chloroform and combined butanol fractions against susceptible bacterial isolates.

\begin{tabular}{llll}
\hline Bacterial isolates & $\begin{array}{l}\text { C-CHLORO } \\
(\mathrm{mg} / \mathrm{ml})\end{array}$ & $\begin{array}{l}\text { C-BUT } \\
(\mathrm{mg} / \mathrm{ml})\end{array}$ & STREP(mg/ml) \\
\hline B. anthracis (LIO) & 0.88 & 0.88 & 0.25 \\
B. cereus (NCIB 6349) & 0.88 & 1.7 & 0.06 \\
B.stearothermophilus (NCIB) & 3.5 & 3.5 & 0.06 \\
B. subtilis (NCIB 3610) & $\mathrm{ND}$ & $\mathrm{ND}$ & 0.25 \\
C.sporogenes (NCIB 532) & 3.5 & 3.5 & 0.06 \\
C. pyogenes (LIO) & $\mathrm{ND}$ & $\mathrm{ND}$ & 0.13 \\
E. coli (NCIB 86) & 0.11 & 0.22 & 0.50 \\
K. pneumoniae (NCIB 418) & 3.5 & 3.5 & 0.50 \\
M. luteus (NCIB 196) & 0.88 & 1.75 & 0.25 \\
P. vulgaris (LIO) & 3.5 & 3.5 & 0.50 \\
Ps. Aeruginosa & 3.5 & 3.5 & 0.50 \\
Salmonella (LIO) & 3.5 & 1.75 & 0 \\
Shigella (LIO) & 0.44 & 0.44 & 0.25 \\
S. aureus (NCIB 8588) & 0.44 & 0.88 & 0.13 \\
E. faecalis (LIO) & 0.44 & 1.75 & 0.25 \\
\hline
\end{tabular}


Key: $\mathrm{LIO}=$ Locally Isolated Organisms, NCIB $=$ National Collection of Industrial Bacteria, ND $=$ Not determined, C-CHLORO $=$ Combination of Chloroform fractions of the two plant extracts, C- BUT $=$ Combination of Buthanol fractions of the extracts of G. Kola and A. sativum.

The rate of kill of $S$. aureus by chloroform fraction of Garcinia kola, combined butanol and combined chloroform fractions of G. kola and A. sativum at $0.44 \mathrm{mg} / \mathrm{ml}$ revealed that within 90 min of exposure, the percentage of cells killed was $96.5 \%$ for chloroform fraction of G. kola, $76.7 \%$ for combined chloroform fractions and $100 \%$ killing was achieved by combined butanol fractions of G. kola and A. sativum. At $120 \mathrm{~min}$ of exposure with the active fractions, the number of the cells killed by chloroform fraction of $G$. kola increased to $98.8 \%$ and $93 \%$ for combined chloroform fractions of the plant extracts (Fig. 1).

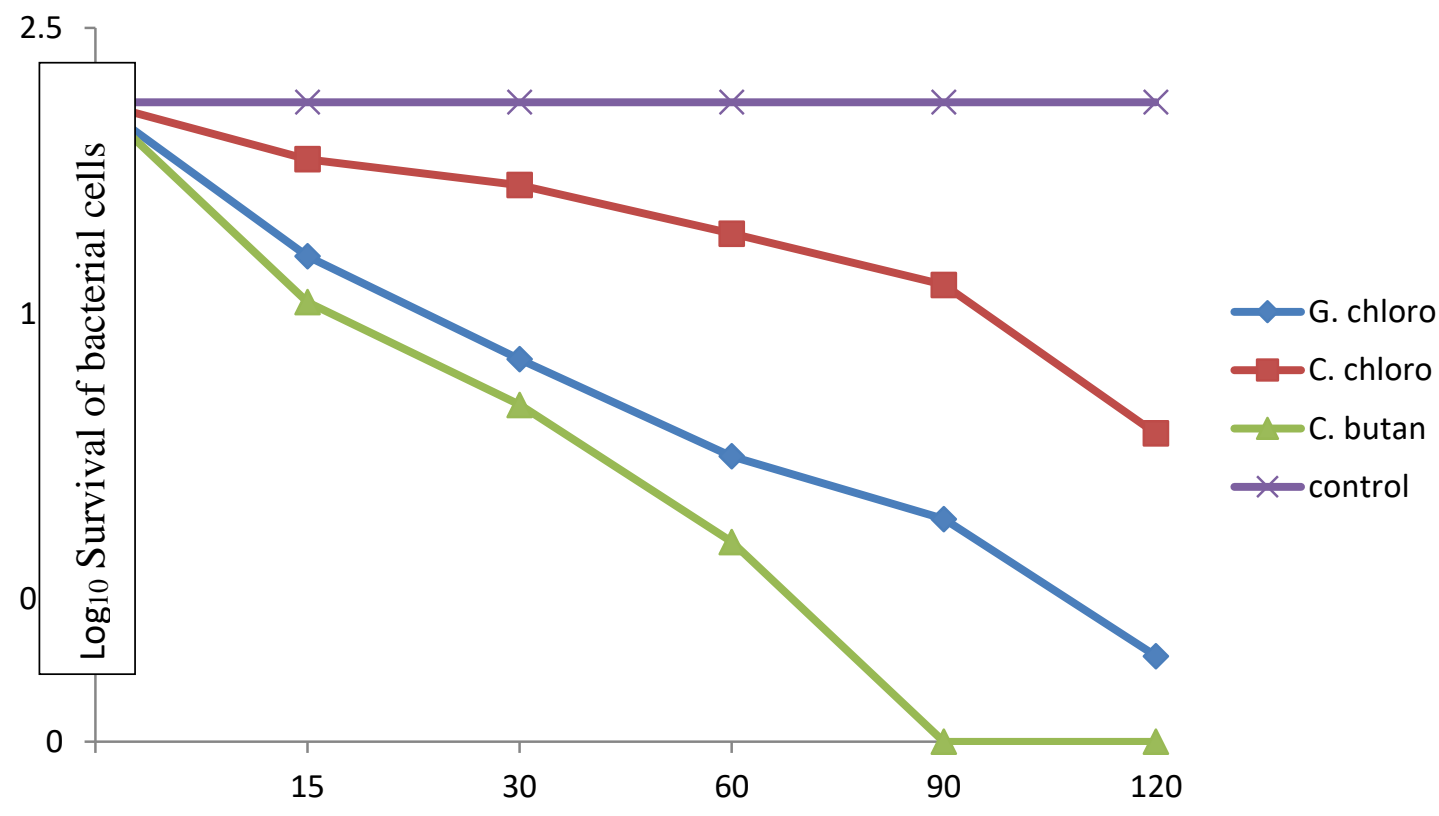

Time (min)

Fig 1: Rate of kill of S. aureus by chloroform fraction of G. kola (G.chloro), combined chloroform fraction (C.chloro) and combine butanol fractions (C.butan) of methanolic extracts of G. kola and A. sativum at different time interval with $2 \times M I C$.

The percentage of the K. pneumonia killed using $3.5 \mathrm{mg} / \mathrm{ml}$ of chloroform fraction of G. kola, butanol fraction of $A$. sativum, combined chloroform and combined butanol fractions of G. kola and A. sativum showed that at $60 \mathrm{~min}$ of contact time, $100 \%$ killing were achieved by butanol fraction of A. sativum and combined butanol fractions of G. kola and A. sativum while at $120 \mathrm{~min}$., the percentage of the organisms killed by chloroform fraction of G. kola increased to $98.9 \%$ and $89.4 \%$ for combined chloroform fractions of the plant extracts (Fig. 2).

The effectiveness of an antibacterial agent is said to be measured by its bactericidal and bacteriostatic ability (20). In vitro rate of killing analysis are shown as the rate at which a particular concentration of an antibacterial agents inhibit visible growth of cells and its one of the most vital ways to determine tolerance (20). The effect of the different fractions obtained from crude methanol G. kola and A. sativum extracts against the organisms individually and in combination in this study appears to depend on time and concentration. Increase in contact time of the bacterial cells with the bioactive fractions as well as increase in concentration led to increase in the number of cells killed and this agrees with the findings of (9) from his study on antibacterial potential of red grape juice and red wine on Listeria monocytogenes.

From the result of the rate of kill analysis, it was discovered that the combined butanolic fractions of G. kola and A. sativum exhibited the highest percentage of killing against both $S$. aureus (Gram positive) and K. pneumonia (Gram negative). This justifies the utilization of alcohol in 
extracting bioactive components from plants in traditional medicine. Higher activity of the combined butanol fraction also confirm the findings of another researcher (21) who reported that alcoholfraction of plant extract showed better activities and that this might be attributed to the higher polarity of butanol and thus more affinity for the active components of G.kola.

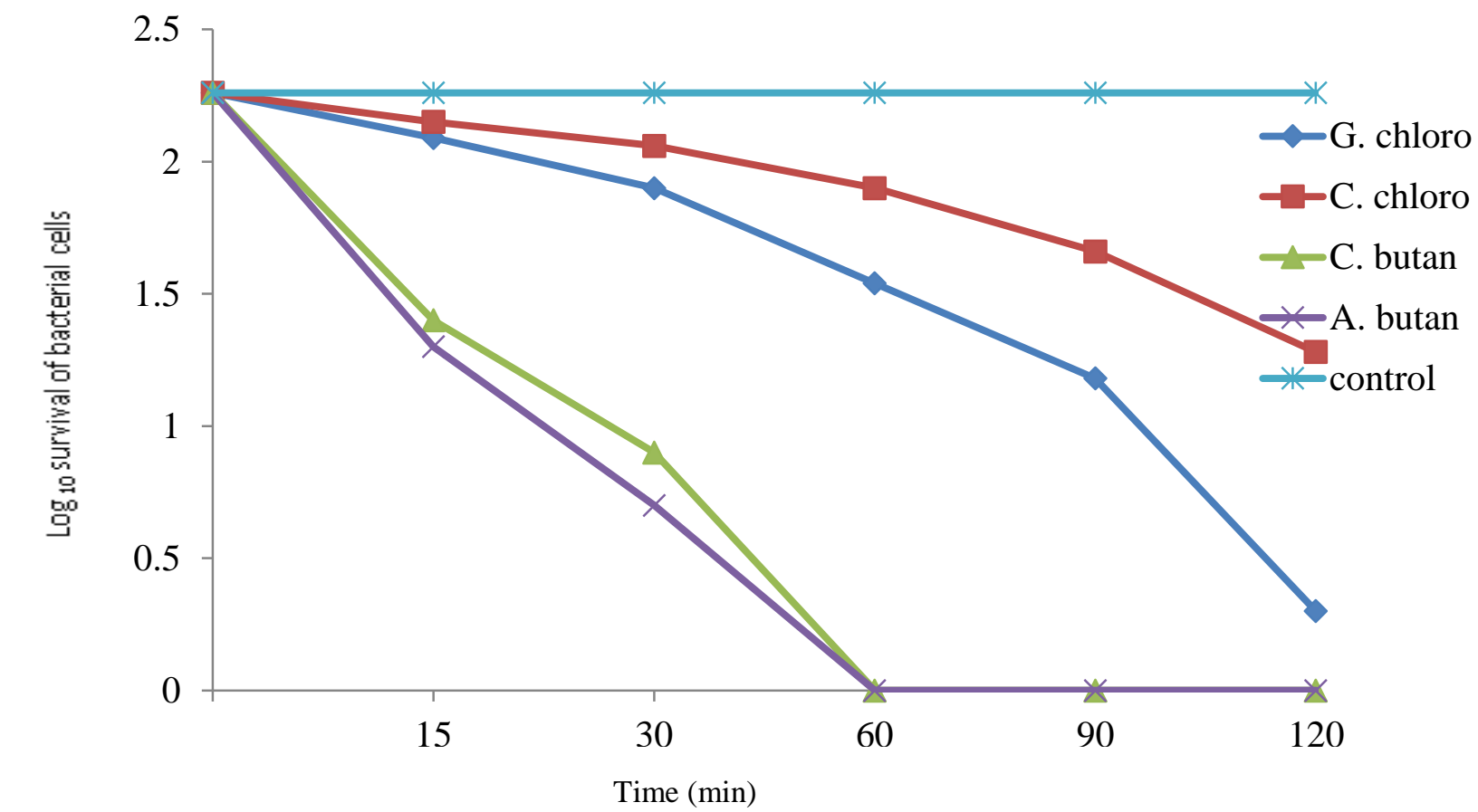

Fig 2:Rate of kill of K. pneumonia by chloroform fraction of G. kola (G.chloro), butanol fraction of A. sativum (A.butan), combined chloroform fractions (C.chloro) and combine butanol fractions (C.butan) of methanolic extracts of G. kola and A. sativum at different time interval with $2 \times$ MIC.

\section{CONCLUSION}

All the fractions obtained from the methanolic extracts of G. kola and A. sativum individually and even in combined form possess the potential of providing relief to antibiotic resistance experienced in the recent times with pathogenic organisms as seen in this study. With the antimicrobial potential exhibited by these plant extracts especially when combined, there is need to assess the main mechanisms of action of these plants extracts in combination and antimicrobial activities of a wider strains of each organisms that shows susceptibility to these plants so as to adequately explore their potential.

\section{REFERENCES}

[1] Dias D. A., Urban S, and Roessner U. (2012). A Historical Overview of Natural Products in Drug Discovery. Metabolites 2(2): 303-336.
[2] Panche A. N., Diwan, A. D. and Chandra S. R. ( 2016). Flavonoids: an overview. Journal of Nutritional Science, 5:47.

[3] Das, Q., Islam M. R., Marcone M. F., Warriner K. and Diarra M. S. (2016). Potential of berry extracts to control foodborne pathogens, Food Control: 1-13.

[4] Fair R. J. and Tor Y. (2014). Antibiotics and Bacterial Resistance in the 21st Century. Perspective in Medicinal Chemistry 6:25 -64

[5] Parekh, J. and Chanda S. (2007). In vitro antimicrobial activity of Trapa natans Linn. Fruit rind extracted in different solvents. African Journal of Biotechnology, 6: 766-770.

[6] Harmala P., Vuorela H., Tornquist K. and Hiltunen R. (1992). Choice of Solvent in the Extraction of Angelica archangelica Roots with Reference to Calcium Blocking Activity. Planta Medica 58(2):176-183

[7] Jehan B., Shehla K. and Mohammad S., (2013). Antimicrobial Potentials of Fresh Allium Cepa against Gram Positive and Gram Negative Bacteria and Fungi. Pakistan Journal of Botany 45(S1): 1-6. 
[8] Eloff J. N., (1998). Which extractant should be used for the screening and isolation of antimicrobial components from plants? Journal of Ethnopharmacology 60(1): 1-8.

[9] Akinpelu, D. A., Aiyegoro, O. A. and Okoh, A. (2008), In Vitro Antimicrobial and Phytochemical Properties of Crude extract of Stem Bark of Afzelia Africana (Smith). African Journal of Biotechnology 7: 3665-3670.

[10] Kris-Etherton, P. M., 2002. Bioactive compounds in foods: Their role in the prevention of cardiovascular disease and cancer. Jounal of American Medicine 113: 71-88.

[11] Sibanda T. and Okoh A. I., (2008). In vitro Antibacterial Regimes of Crude Aqueous and Acetone Extract of Garcinia kola Seeds; Journal of Biological Science 8(1) 149-154.

[12] Ezeifeka G O, Orji M U, Mbata T I And Patrick A O., 2004 Antimicrobial activity of Cajanas cajan, Garcinia kola and Xylopia aethiopica on pathogenic microorganisms; Biotechnology 3(1): 41-43

[13] Gangadhar M., Shraddha K. and Ganesh M. (2012). Antimicrobial screening of Garlic (Allium sativum) extracts and their effect on Glucoamylase activity in-vitro. Journal of Applied pharmaceutical Science, 2(1): 106-108

[14] Fahad A. M. Alzowahi, Ahmed Abu-Taleb, Amani AsSuhbani and Kadam T. A., (2013). The inhibitory effects of garlic extract and its fractions against some Enterobacteriaceae sp isolated from sprouted Mung bean. International Journal of Current Microbiology and Applied Science 2(7): 104-115.

[15] Akinpelu D. A. and Kolawole D. O., (2004). Phytochemistry and antimicrobial activity of leaf extract of Piliostigma thonningii (Schum); Science focus, 7 64-70.

[16] Odenholt I, Lowdin E and Cars O (2001). Pharmacodynamics of telithromycin in vitro against respiratory tract pathogens; Antimicrobial Agents and Chemotherapy, 45(1) 23-29.

[17] Damisa D. , Babayi H., Odeh O. E., Yahaya T. A. and Salawu O. A.(2015). Investigating the Toxicity and Antimicrobial Activity of Garcinia kola Extracts. World Journal of Pharmaceutical Research 4(4): 57-67.

[18] Idu M., Obayagbona N. O., Oshomoh E. O., Erhabor J. O., (2014). Phytochemicals of Chrysophyllum albidum, Dacryodes edulis, Garcinia kola chloroform and ethanolic root extracts and their antimicrobial properties. Journal of Intercultural Ethnopharmacology 3(1):15-20

[19] Holezt F. B., et al. (2002). Screening of some plants used in the Brazilian folk medicine for the treatment of infectious diseases. Member Institute of Oswaldo Cruz, 6(7): 1027-1031.

[20] Nostro A., Cannatelli M. A., Grisafi G. and Alonszo V. (2001). The effect of Nepata cataria extract on adherence and enzyme production of Staphylococcus aureus. International Journal of Antimicrobial Agents.18:583-585.

[21] Akerele J. O, Obasuyi O, Ebomoyi M. I., Oboh I. E., Uwumarongie O. H (2008). Antimicrobial activity of the ethanol extract and fractions of the seeds of Garcinia kola Heckel (Guttiferae). African Journal of Biotechnology 7 (2): 169-172.

ISSN: $2456-1878$ 